\title{
Improvement in coffee production and economic gains by the farmers through support of coffee cooperative societies in Kenya
}

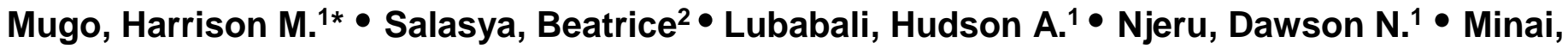 \\ James M. ${ }^{1}$
}

${ }^{1}$ Kenya Agricultural and Livestock Research Organization - Coffee Research Institute, Box 4 - 00232 , Ruiru, Kenya.

${ }^{2}$ Kenya Agricultural and Livestock Research Organization, Box 57811-00200, Nairobi, Kenya.

${ }^{*}$ Corresponding author. E-mail: mugohmu@yahoo.com

Accepted 15 ${ }^{\text {th }}$ April, 2019.

\begin{abstract}
Kenya produces Arabica coffee that is exported as a premium coffee because of its high quality. The production in the Country declined in late 1980s to 2010 and has generally stagnated. The shortage of coffee seedlings for expansion and replanting in the traditional and new coffee growing areas has aggrevated the production problem. To mitigate this, Coffee Productivity Project (CPP) was initiated to support selected coffee farmers Cooperative Societies through a Public Private Partnership (PPP) initiative to produce and avail the planting materials closer to the farmers. At the end of the project period, a social economic survery was conducted to assess the impact of the project. The study was conducted in eight (8) Farmers Cooperative Societies (FCS) in eight (8) coffee growing counties. A total of 241 farmers were interviewed. The data was collected using formal pre-tested questionnaire and analysed using IBM SPSS software version 15 where the quantitative statistics was applied. The results showed that production of coffee seedlings by the selected Cooperatives increased by $355 \%$. On average, the number of coffee trees per farmer increased by $40 \%$ in the project area while the area planted with coffee increased by $35.4 \%$. Overall, the average coffee cherry produced per farmer in the project area increased by $63 \%$. The average pay out per kilogram of Cherry increased by $100 \%$ from Ksh 36.74 in year 2012/2013 to Ksh 73.64 in year 2016/2017. The findings during this study implied that, the support of the Cooperatives promoted the expansion of coffee farming in the project areas thus contributing to the improvement in coffee production, increased farmers' earnings and improved livelihood.
\end{abstract}

Keywords: Coffee, seedlings, cooperative societies, coffee cherry, livelihood.

\section{INTRODUCTION}

Coffee is the most important commodity in the international agricultural trade, where it represents a significant source of income to Latin American, African and Asian countries (DaMatta, 2004). The coffee industry is worthy over US\$100 billion worldwide (Andrew, 2019). In Kenya, coffee earnings during the year 2011 were about US\$277.7 million (Coffee Board of Kenya, 2012). Currently, the coffee industry in Kenya contributes an average of KShs.20 billion (US\$ 198.6 million) per year in foreign exchange earnings (International Coffee Organization, 2019). This is a decline from the year 2011.

Coffee produced in Kenya is exported as a premium Arabica coffee with most of it $(70 \%)$ being produced in Central Kenya, Kisii, Nyanza, Bungoma, Nakuru , Kericho, Machakos and Taita Taveta Counties by smallscale holders through the Cooperative Societies. In 2012, 
the Country had about 150,000 coffee farmers with an estimated six million workforce employed directly or indirectly in the coffee sub sector (Howden, 2012). At present, the acreage under coffee production in the country is about 114,500 hectares (Internationa coffee organization, 2019).

Kenya has recorded a decline in coffee production from a high of 130,000 tonnes in 1988/89 to yearly average of 50,000 tonnes as reported in 2012 (Coffee Board of Kenya, 2012). A number of reasons are associated with this decline, these include the collapse International Coffee Organization's quota system that led to decline in coffee prices, high cost of production, unfavorable weather conditions such as drought and increased incidences of coffee pests (insects, diseases and weeds). These have led to an increased number of farmers opting out of coffee farming to other enterprises. The management of coffee pests, especially the diseases significantly constrain profitable production of coffee in Kenya. For instance, in most coffee growing areas in Kenya, three traditional coffee varieties namely SL $28, \mathrm{SL}$ 34 and K7 are predominant. These varieties are susceptible to major coffee diseases particularly the Coffee Berry Disease (CBD) and Coffee Leaf Rust (CLR) hence farmers use a lot of fungicides to manage the two diseases. Through outstanding selections from a multiple cross program involving CBD resistant donor parents; Rume Sudan, HDT, K7 and Catimor; and high yielding, good quality but susceptible cultivars; SL 28, SL 34, Bourbon and Tanganyika drought resistant selections followed by backcrossing and selfings, Kenya developed improved coffee varieties; Ruiru 11 released in 1985 (Omondi and Owuor, 1992) and Batian in 2010 (Gimase et al., 2014, 2015) that are resistant to both CBD and CLR.

The improved varieties addressed the high costs of coffee production and environmental concerns by eliminating the need for intensive fungicides spraying regimes to control CBD and CLR. These varieties resulted for high demand of the seedlings by farmers. The high demand constrained the existing facilities at Coffee Research Institute (CRI) to produce and supply the seedlings of the improved coffee varieties to the farmers. In response, it prompted CRI to seek for grants from development partners (European Union) in order to address the issue of seedlings production. Through Coffee Productivity Project (CPP) grant support, Coffee Research Institute (CRI) partnered with farmer based Cooperative Societies to produce and supply coffee seedlings of the improved varieties to farmers. The Project was implemented for a period of four (4) years. A study was carried out to determine the impact of the project on coffee production and the economic earnings by the farmers. This paper highlights the extent of improvement in coffee production and the subsequent economic gains by the farmers from the Cooperatives where the project was implemented.

\section{MATERIALS AND METHODS}

\section{Study sites/areas}

The Coffee Productivity Project (CPP) supported 14 coffee growing Counties in Kenya to produce and supply coffee seedlings to farmers. The impact assessment of the project to the farmers was conducted in eight (8) Counties (Figure 1) with Farmers' Cooperative Societies (FCS) that partnered with $\mathrm{CRI}$ in the implementation of CPP. The Counties surveyed included Nandi, Kericho, Homa Bay, Bomet, Nakuru, Kirinyaga, Meru and Tharaka Nithi. Four (4) of the Counties (Kirinyaga, Tharaka Nithi, Meru and Nakuru) represented the traditional coffee growing Counties whereas the other four (4) (Nandi, Bomet, Homa Bay and Kericho) represented the new coffee growing Counties.

\section{Sampling procedures and sample size}

Purposive sampling was used to select the eight Cooperative Societies where farmers sampled were affiliated to. The sampled Societies represented in equal numbers, the traditional and new coffee growing regions in Kenya. In each Society, about 30 farmers were randomly sampled and interviewed. To select the specific farmer to interview, trained enumerators walked along randomly selected transect lines and selected every $\mathrm{K}^{\text {th }}$ farmer, where $\mathrm{K}$ depended on the population density. Every $\mathrm{K}^{\text {th }}$ farmer was interviewed along the transect.

\section{Data collection}

Trained enumerators collected and managed the data using questionnaires that were uploaded in the Open Data Kit (ODK) installed in smart phones. The data collected from farmers included household and farm characteristics. Household data included gender, age, education level, primary and secondary occupation of the respondent and of the household head, and the household size, disaggregated by gender and age, and main sources of farm income. Data on farm characteristics included area under coffee and number of coffee trees, area under other major crops as well as changes in coffee production over the last five years. Data was also collected on earnings from coffee and their uses. The responses were entered into smart phones and electronically transmitted to a central server in real time after verification for accuracy and consistency by each County data collection supervisor.

\section{Data processing}

The data was collected and exported to an excel 


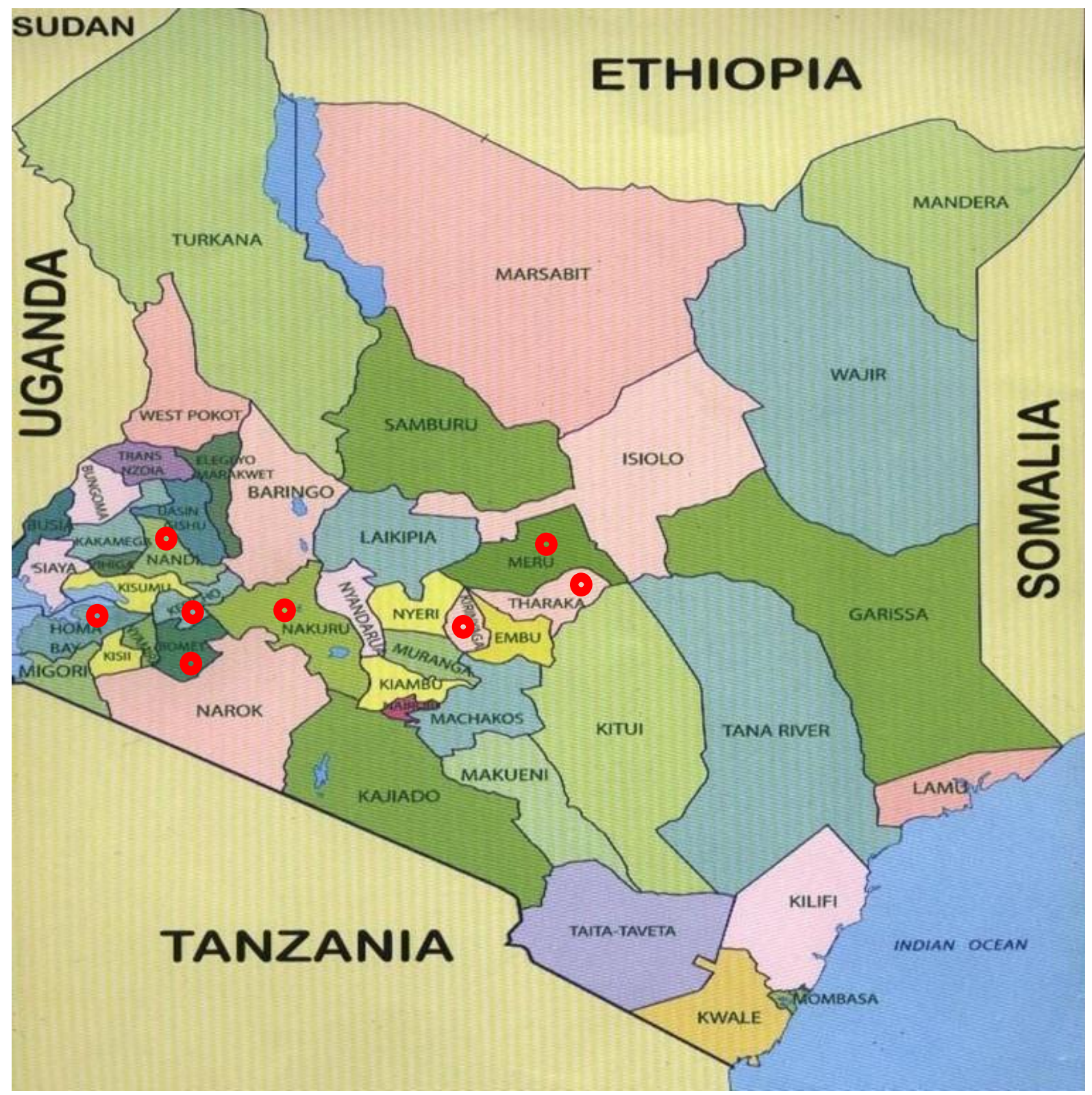

Figure 1. Coffee growing counties sampled (marked with red dots).

spreadsheet in a Comma-Separated Value (CSV) format after cleaning, validation and collation for accuracy and consistency. The excel data files were eventually exported to IBM SPSS software version 15 for analysis. Quantitative analysis mainly on means was applied on the key variables in the data set. The results were presented in form of tables, graphs and charts.

\section{RESULTS AND DISCUSSION}

\section{Cooperative societies and coffee farmers sampled}

The Cooperative Societies and the number of coffee farmers sampled per County are shown in Table 1. A total of 241 coffee farmers were interviewed across the eight (8) Cooperatives surveyed. All the farmers interviewed were affiliated to the Cooperative Societies where they delivered their coffee produce.

\section{Coffee production}

The average land owned per household (total land owned) was less than 3 acres (Table 2). Eighty two percent $(82 \%)$ of the land was cultivated (Table 2$)$. The availability of uncultivated land was an opportunity for new coffee establishment that led to the expansion of 
Table 1. Number of sampled farmers by county and by FCS.

\begin{tabular}{llc}
\hline County & Coop society & Number of farmers \\
\hline Kericho & Kabngetuny & 33 \\
Homa Bay & Kabondo & 29 \\
Bomet & Kitchumo & 29 \\
Kirinyaga & Mutira & 30 \\
Meru & Katheri & 30 \\
Tharaka Nithi & Kiriani & 30 \\
Nakuru & Mutungati & 30 \\
Nandi & Kapsaos & 30 \\
Total & & 241 \\
\hline
\end{tabular}

Table 2. Average amount of land (acres)owned and used by the sampled households.I

\begin{tabular}{lc}
\hline Category & Area (acres) \\
\hline Total land owned & 2.95 \\
Owned land cultivated & 2.37 \\
Owned land uncultivated & 0.58 \\
Rented in land cultivated & 0.30 \\
Rented in land uncultivated & 0.01 \\
Rented out land cultivated & 0.05 \\
Rented out land uncultivated & 0.00 \\
\hline
\end{tabular}

coffee.

\section{Coffee seedlings production in the sampled cooperative societies}

On average in year 2012/2013 the annual seedlings production was about 15,428 per society (Figure 2). The trend increased to an average of 70,245 seedlings per year per society in year 2015/2016 that translated into $355 \%$ increase in seedlings production. There was significant increase in seedlings produced in years $2014 / 15,2015 / 2016$ and 2016/17 after the project was implemented by the FCSs compared to years 2012/13 and $2013 / 14$ at $\mathrm{P}<0.05$ ) (Figure 2). In year 2016/2017, seedlings production registered some decline which was attributed to seedlings carried over from previous year hence limiting space for more seedlings production in the existing coffee nursery facilities in the Cooperatives. However, the seedlings produced in 2016/2017 was still significantly higher $(\mathrm{P}<0.05)$ than before the project started. Prior to the support of the Cooperatives to produce coffee seedlings, farmers experienced challeges in accessing the seedlings of improved coffee varieties. The demand was high while the supply was low. However, there were a clear indication that the demand for seedlings was being met by the partnering Cooperatives as spilling over of the seedlings was observed between year 2015/2016 and 2016/2017.

\section{Population of coffee trees}

The unavailability of coffee seedlings to the farmers constrained the expansion of coffee in traditional and non traditional coffee growing areas. This subsequently affected the anticipated increase in national coffee production. Supporting the Cooperative Societies to construct the coffee nurseries and raise seedlings enabled the farmers to plant more coffee.This led to increased population of coffee trees owned by the existing and new farmers. The average number of trees per farmer increased from 326 in 2012/2013 to 457 in 2016/2017 showing a 40\% increase (Figure 3).

\section{Area under coffee compared to other crops from sampled farmers}

Farmers especially the smallhoders, normally diversify their activities because of the risk involved in farming and limited land holdings. As a result, coffee farming competes with other enterprises such as tea, macadamia, horticulture, maize, avocado and dairy. Unlike in large coffee estates, FCSs are owned by smallscale farmers who come together to bulk their produce for marketing purposes. To mitigate the risks in farming, the sampled farmers also had other crops including tea, horticulture, maize, bananas, Macadamia, Avocados, Beans, Miraa, Potatoes, Cassava and Sugarcanes (Table 3 ). Moreover, coffee is a shade loving crop,that need to be grown under other trees for shade.

The survey examined the changes in area under the various crops planted by the sample farmers over the period when the CPP project was implemented. The area under coffee increased by $35.4 \%$ (Table 3). However, the increase was higher up to 2015/2016 (50\%) but reduced between $2015 / 2016$ and 2016/2017. It was observed that in 2016/2017 some farmers uprooted the old traditional coffee varieties they had for a long time and planted the improved varieties. This scenario was mainly observed in Kericho County where farmers uprooted most of their coffee to plant the improved coffee varieties as they realised the coffee seedlings were more readily available than before. Area under other crops either increased with a very small margin or reduced, implying that coffee was a competitive farm enterprise among the sampled farmers during the project period (Table 3).

\section{Quantity of coffee cherry delivered to the societies}

Overall, the project led to an increase in both the area under coffee and the number of coffee trees per farmer as indicated in the previous sections. Consequently there was an increase in quantity of coffee harvested and delivered to factories for wet processing from the study areas. The average quantity of cherry delivered per farmer increased by $63 \%$ from $2012 / 2013$ to $2016 / 2017$ 


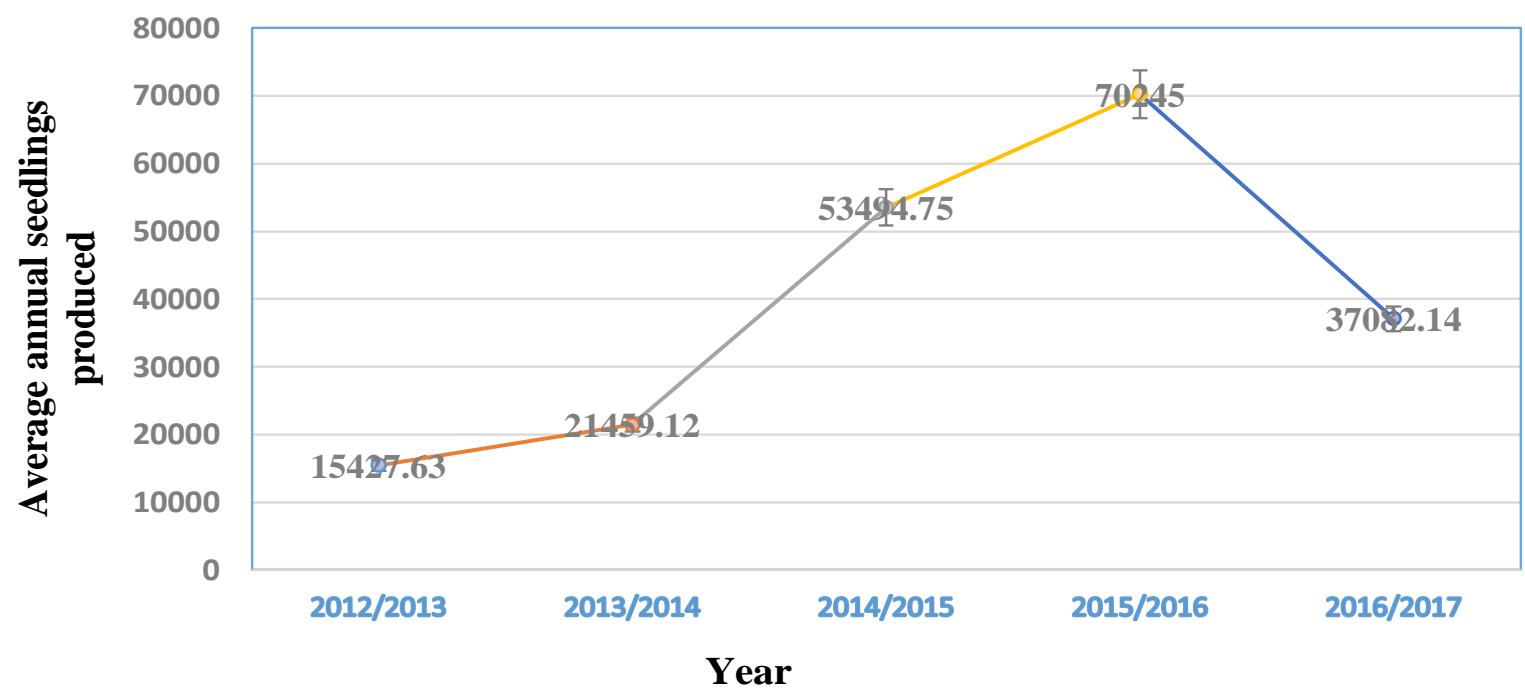

Figure 2. Average annual seedlings production per sampled FCS.

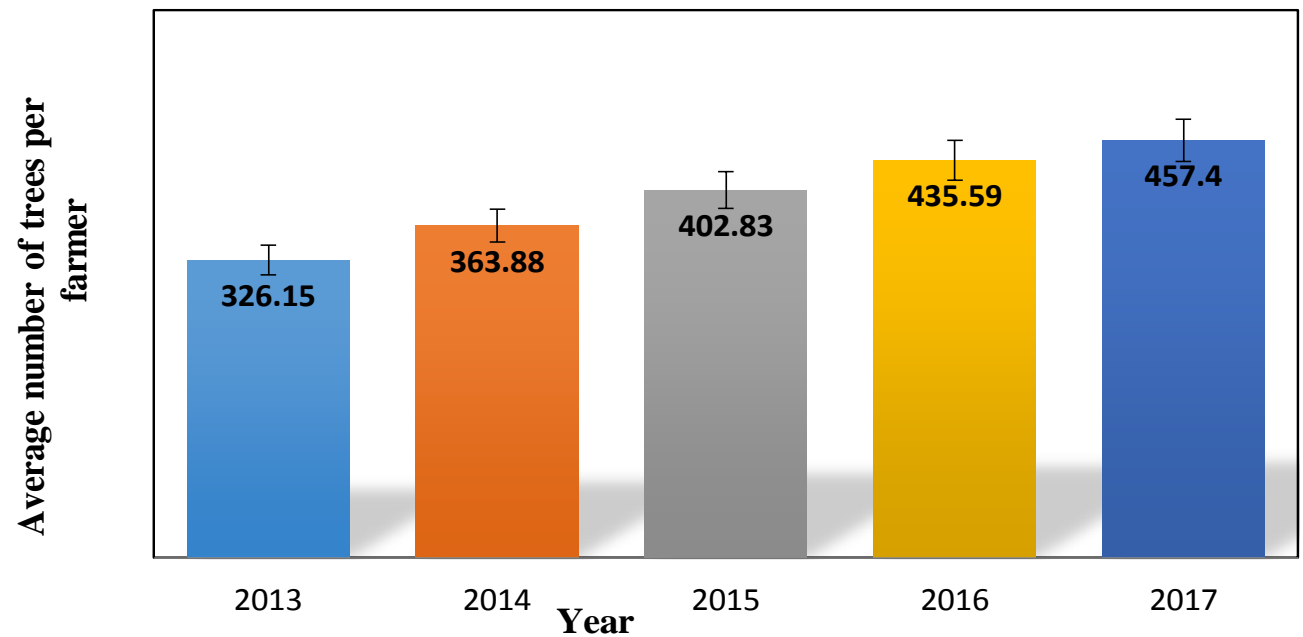

Figure 3. Average number of coffee trees per farmer from 2013 to 2017.

(Figure 4). The highest increase was between 2013/2014 and $2014 / 2015$ (about 17\% increase for both). Given that the newly planted coffee trees from the project area were not in production by then, the increase was attributed to improved coffee husbandry. The other substantial increase was between 2015/2016 and 2016/2017 (14\%). The increased cherry produced and delivered during this period, was attributed to coffee trees planted in 2014 that came into production in year 2017.

\section{Income earnings by sampled farmers}

\section{Main sources of income and farm incomes from sampled farmers}

Of the 241 farmers interviewed, farming was the main occupation of $224(93 \%)$, the rest were in formal employment $(2 \%)$, self-employment $(3 \%)$ and other offfarm sources (2\%) (Figure 5 ). The main sources of farm income from the sampled households included coffee, dairy cattle, bananas, maize, tea, macadamia and horticulture (Table 4). Coffee was the main source of income for all the farmers interviewed except one, who had just planted the coffee and had not started harvesting.

\section{Coffee pay out/earnings from Samped farmers}

The notable increase in cherry production and delivery to the factories (Figure 4) was complemented with improved coffee pay outs (Figure 6). The average pay out per kg of cherry increased from Ksh 36.74 in year 2012/13 to Ksh 
Table 3. Mean area (acres) under various crops per household.

\begin{tabular}{lcccccc}
\hline \multirow{2}{*}{ Crop } & \multicolumn{5}{c}{ Year } & \multirow{2}{*}{ \% change } \\
\cline { 2 - 6 } & $\mathbf{2 0 1 2 / 2 0 1 3}$ & $\mathbf{2 0 1 3 / 2 0 1 4}$ & $\mathbf{2 0 1 4 / 2 0 1 5}$ & $\mathbf{2 0 1 5 / 2 0 1 6}$ & $\mathbf{2 0 1 6 / 2 0 1 7}$ & \\
\hline Coffee & 0.48 & 0.54 & 0.58 & 0.72 & 0.65 & 35.4 \\
Tea & 0.75 & 0.76 & 0.79 & 0.80 & 0.83 & 10.7 \\
Horticulture & 0.29 & 0.27 & 0.27 & 0.28 & 0.28 & 3.4 \\
Maize & 1.01 & 0.89 & 0.97 & 0.99 & 1.03 & 1.9 \\
Bananas & 0.18 & 0.17 & 0.18 & 0.18 & 0.19 & 5.6 \\
Others & 0.55 & 0.62 & 0.66 & 0.69 & 0.69 & 25.4 \\
\hline
\end{tabular}

NB: Others include sweet potatoes, groundnuts, avocados, beans, Miraa, potatoes, cassava, and sugarcane.

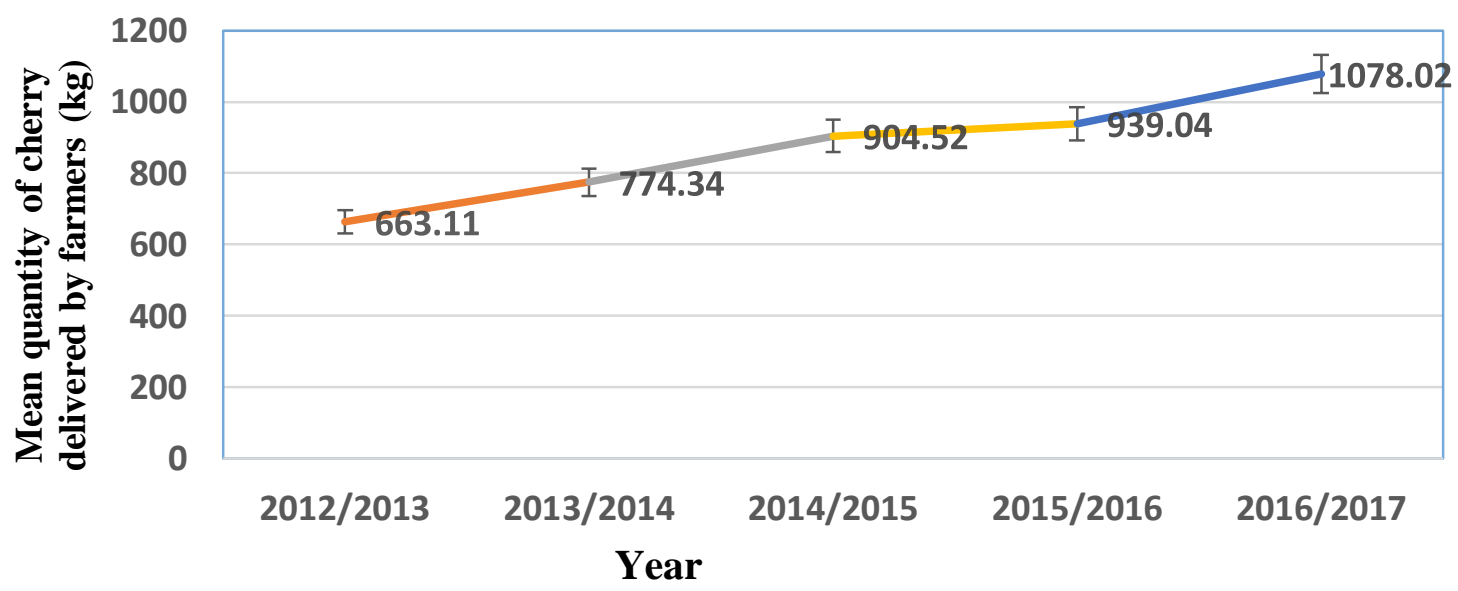

Figure 4. Average quantity $(\mathrm{kg})$ of coffee cherry produced by sampled farmers.

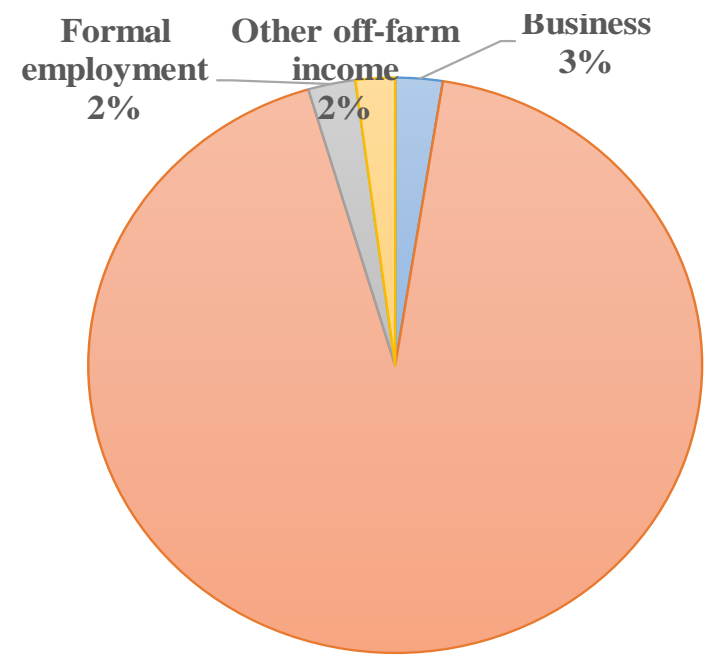

Farm Income 93\%

$\square$ Business $\square$ Farm Income $\square$ Formal employment $\square$ Other off-farm income

Figure 5. Main sources of income for the sampled households.

73.64 in year 2016/17 in areas where the project was conducted (Figure 6). This was an increase of $100 \%$ per
FCS (Figure 6). This increase in pay out was attributed to better quality coffee produced by the farmers following 
Table 4. Main sources of farm income for the sampled households.

\begin{tabular}{lcc}
\hline Source & No. of farmers reporting & Percentage (\%) \\
\hline Coffee & 240 & 96.6 \\
Dairy & 89 & 36.8 \\
Bananas & 51 & 21.8 \\
Maize & 47 & 19.5 \\
Tea & 42 & 17.4 \\
Macadamia & 42 & 17.4 \\
Horticulture & 38 & 15.8 \\
Other crops & 33 & 13.7 \\
\hline
\end{tabular}

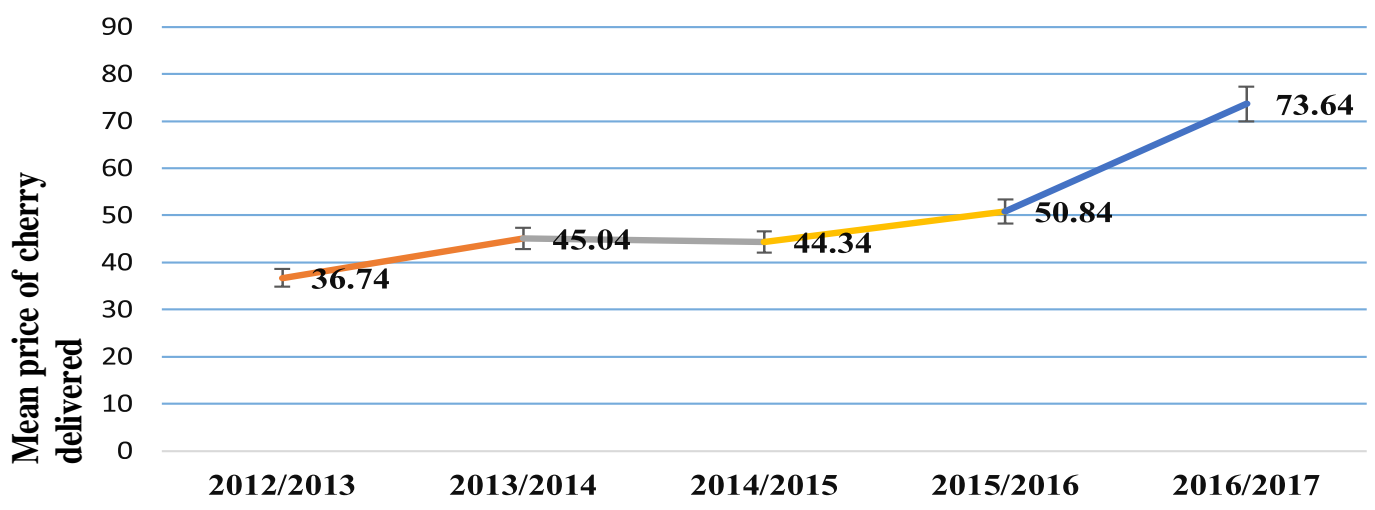

Year

Figure 6. Mean pay out per kg of cherry per sampled FCS.

improvement on coffee husbandry among others. The FCSs realised premium coffee grades/classes that led to increased pay out per kg of cherry.

\section{Impact of income from coffee on various household expenditure items}

On average the highest impact of the income from coffee was on children education. Fourty eight percent $(48 \%)$ of the income was used to pay school fees. Food ranked in second position at $17 \%$ after education indicating the importance of coffee in food security and alleviating hunger. Clothing, home improvement and loan repay out ranked third at $5 \%$ each. The rest of the expenditure items such as health and savings took less than 5\% (Figure 7). Through children education there was anticipation of improved livelihood of the households in future. In addition income from coffee played key role in improving the food security of the farmers as the income from the produce was used to buy food.

\section{CONCLUSION}

The support to the Farmers Cooperative Societies through Public Private Partnerships initiative increased the production and supply of seedlings of the improved coffee varieties to farmers that led to increased area under coffee in the regions where the project was implemented. This led to increased coffee production and pay out to coffee farmers in those areas. The better earnings by the coffee farmers through cooperatives support improved and impacted on various household expenditure items. Children education and food security benefitted most from the improved farmers' earnings. Hence, it was evident that when cooperatives' organizational capacities are strengthened, they can constitute sustainable business models for up scaling research innovation, responding to market requirements and translating productivity enhancement into increased income and better livelihood.

\section{ACKNOWLEDGEMENTS}

We wish to thank the European Union (EU) and the Government of Kenya (GoK) for financing this Project. We also acknowledge the support of the County Governments and Kenya Agricultural and Livestock Research Organization (KALRO) during the project implementation. Finally we acknowledge the Sub 


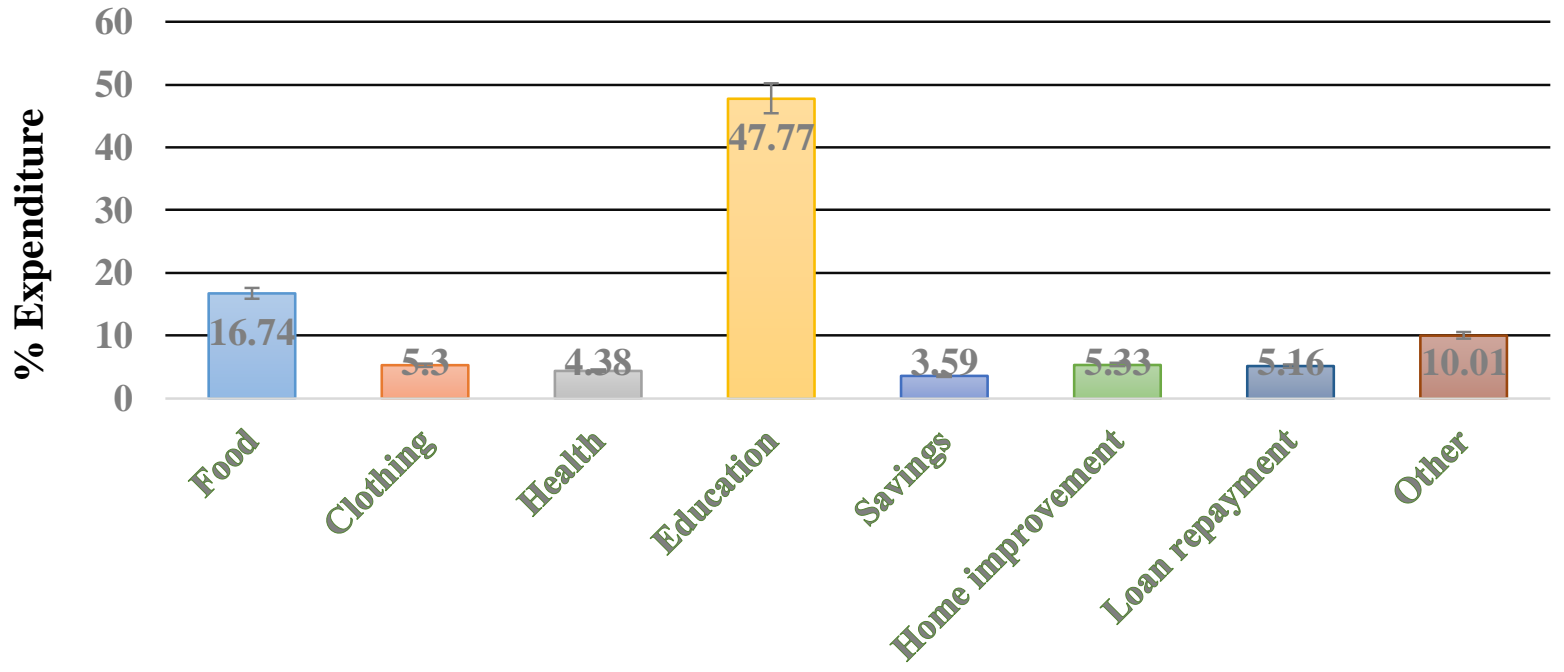

Figure 7. Expenditure of income from coffee.

grantees, Project Impementation Committee and Coffee Research Institute (CRI) teams (Technical and Coordination) for their dedication in ensuring the project was a success.

\section{REFERENCES}

Andrew M (2019). The Global coffee Industry (online). Available from https://globaledge.msu.edu/blog/post/55607/the-global-coffeeindustry.

Coffee Board of Kenya (2012). History of Coffee. Available from http://www.airc.go.ke/?option=com_contact\&view=contact\&id=191\%3 Ac offee-board-of-kenya\&catid=116\%3Aregulatory-licensing-amarketing-agencies\&ltemid $=98$.

DaMatta FM (2004). Ecophysiological constraints on the production of shaded and unshaded coffee. A Review. Field Crop Res. 86(2-3):99114.

Gimase JM, Thagana WM , Kirubi DT, Gichuru EK, Gichimu BM (2014). Genetic characterization of Arabusta coffee hybrids and their parental genotypes using molecular markers. Plant Cell Biotechnol. Mol. Biol. 15(1\&2):31-42.

Gimase JM, Omondi CO, Kathurima CW (2015). Improvement of coffee by interspecific hybridization (Review Paper). J. Agric. Crop Res. 3(3):41-46.

Howden D (2012). Kenya's_coffee_wars The Independent, Retrieved 27 August 2013.

International Coffee Organization (2019). Coffee production and marketing in Kenya (Online). Available from https://wwww.iconairobimeeting.com/wwww.www.afa.go.ke

International Coffee Organization (2019). History of Kenya coffee (Online). Available from https://wwww.iconairobimeeting.com/wwww.www.afa.go.ke.

Omondi CO, Owuor JBO (1992). The performance of interspecific crosses and backcrosses involving Arabica and tetraploid Robusta coffee species. Kenya Coffee. 57(666):1307-1312.

http://www.sciencewebpublishing.net/jacr 